\title{
Efektivitas Modul Dalam Pembelajaran Sosiologi Berbasis Weblog Terhadap Peningkatan Pemahaman Materi Peserta Didik di SMAN 6 Kota Jambi
}

\author{
Yumna Aulia Putri ${ }^{1}$, Ike Sylvia ${ }^{2}$, \\ ${ }^{1,2}$ Universitas Negeri Padang; Padang, Indonesia \\ Email: yumnaauliaputri30@yahoo.co.id, ikesylvia@fis.unp.ac.id
}

\begin{abstract}
Abstrak
Sebelum abad 21, modul banyak berbentuk hardcopy. Perkembangan Ilmu Pengetahuan dan Teknologi (IPTEK), maka pada abad 21 pembelajaran dengan metode hardcopy berubah pada pembelajaran online. Tujuan dari penelitian ini adalah untuk membantu peserta didik pada saat memahami materi dalam memecahkan masalah berdasarkan yang dihadapi dalam kehidupan sehari-hari. Penelitian ini menggunakan metode eksperimental dengan rancangan penelitian one group pretest-posttest design. Pengumpulan data dilakukan dengan bantuan instrumen soal berupa pretest dan posttest. Sumber data penelitian ini berasal langsung dari peserta didik kelas XI SMAN 6 Kota Jambi. Subjek penelitian sebanyak 35 peserta didik kelas XI IPS 3 dengan teknik pengambilan sampel secara purposive sampling. Setelah dilakukan tes normalitas dan homogenitas maka untuk analisis data efektifitas modul pada pembelajaran sosiologi berbasis weblog dilakukan dengan uji-t. Hasil penelitian menunjukkan modul pada pembelajaran sosiologi berbasis weblog terbukti efektif sesuai dengan hasil pengujian empiris.

Kata kunci: Efektivitas, Modul, Weblog, Pembelajaran Sosiologi

\section{Abstract}

Before the 21st century, many modules were in hardcopy form. The development of Science and Technology (IPTEK), then in the 21st century learning using the hardcopy method changed to online learning. The purpose of this study is to help students understand the material in solving problems based on what is faced in everyday life. This study used an experimental method with aresearch one group pretest-posttest designdesign. Data collection was carried out with the help of question instruments in the form of pretest and posttest. The data source of this research came directly from students of class XI SMAN 6 Jambi City. The research subjects were 35 students of class XI IPS 3 with the sampling technique using purposive sampling. After the normality and homogeneity tests were carried out, the t-test was used to analyze the effectiveness of the module data on weblog-based sociology learning. The results showed that the module on weblog-based sociology learning was proven effective in accordance with the results of empirical testing.
\end{abstract}

Keywords: Effectiveness, Module, Weblog, Sociology Learning

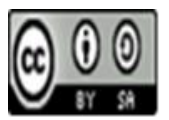

Received: May 5, $2021 \quad$ Revised: June 7, 2021 $\quad$ Accepted: June 9, 2021


Perubahan Ilmu Pengetahuan dan Teknologi (IPTEK) sangat berpengaruh untuk melahirkan kemajuan teknologi yang sedang berkembang pada era ini. Trilling, B., \& Fadel,C (Wijaya, Sudjimat, \& Nyoto, 2016) menjelaskan bahwa terdapat perubahan yang akan terjadi di abad 21. Pada abad ini ilmu pengetahuan dan teknologi kemajuannya makin pesat, itulah sebabnya abad 21 disebut sebagai era digital dengan adanya internet yang sudah menjadi kebutuhan wajib di berbagai bidang termasuk pendidikan terutama perubahan dalam proses pembelajaran. Pendidikan saat ini mempunyai tugas supaya peserta didik dituntut untuk bersiap menghadapi perubahan dan tantangan abad ke-21. Saat ini, rata-rata sekolah mempunyai sarana berupa gedung yang digunakan sebagai laboratorium komputer dan jaringan internet. Hal ini dilakukan guna mempersiapkan semua tantangan yang harus dihadapi anak didik pada abad 21 .

Pendidikan yang maju seyogyanya mengikuti perkembangan teknologi yang terus berkembang. Pada abad 21 saat ini teknologi memegang peranan penting dalam kehidupan manusia. Berdasarkan UU No. 20 Tahun 2003 tentang pendidikan nasional (Tim Grasindo, 2017) maka, dunia pendidikan dituntut untuk terus meningkatkan kualitasnya baik dalam hal sarana dan prasarana termasuk juga kualitas praktik pembelajaran. Disamping itu seorang guru harus profesional dalam memenuhi kebutuhan belajar peserta didik sesuai dengan kemampuannya dalam memanfaatkan teknologi sebagai alat pembelajaran. Pada saat melakukan kegiatan pembelajaran, banyak hal yang harus dipersiapkan guru seperti merancang perangkat pembelajaran yaitu, Rencana Pelaksanaan Pembelajaran (RPP), silabus, media pembelajaran, Lembar Kerja Peserta Didik (LKPD), instrumen evaluasi, modul dan lainnya yang dalam pelaksanaan pembelajaran berjalan sesuai dengan perangkat pembelajaran dan tercapai suatu tujuan pembelajaran. Perangkat pembelajaran berfungsi sebagai pedoman bagi guru agar pembelajaran terarah.

Penerapan media pembelajaran sangat berpengaruh terhadap proses pembelajaran. Dalam permendiknas No. 16 Tahun 2007 mengenai standar kualifikasi akademik dan kompentensi guru mengamanatkan bahwa guru harus dapat menyusun rancangan pembelajaran yang lengkap, menggunakan media pembelajaran yang relavan dengan karakteristik peserta didik dalam proses pembelajaran (Dwipayana, Redhana, \& Juniartina, 2020, p. 20). Salah satu media yang diaplikasikan oleh guru dalam proses belajar mengajar adalah modul, hal ini senada dengan pendapat Ditjen PMPTK Surya Dharma (Depdiknas, 2008, pp. 7-8) yaitu modul merupakan metode pembelajaran mandiri yang menitikberatkan pada kemampuan belajar sesuai dengan materi ajar yang dipelajari peserta didik pada kurun waktu tertentu, sesuai dengan potensi, kondisi dan kiprah peserta didik dengan bantuan tutor, pembimbing atau orang lain, tetapi ini bukan berarti peserta didik bergantung pada mereka. Modul salah satu bentuk bahan ajar yang memiliki format lengkap. Modul adalah kumpulan materi, soal, LKPD, dan evaluasi yang disusun secara runtut berdasarkan pendekatan tertentu.

Modul menjadi salah satu bahan ajar yang memiliki karakteristik-prinsip belajar mandiri (Lasmiyati \& Harta, 2014). Belajar mandiri menurut Oka (Lasmiyati \& Harta, 2014) adalah pembelajaran mandiri merupakan bentuk pembelajaran aktif dan partisipasi dalam pengembangan setiap individu yang tidak terikat dengan adanya guru, dosen, tatap muka di kelas, dan teman sekolah. Sebagian besar modul dalam bentuk cetak, namun saat ini penerapan teknologi untuk mendukung pembelajaran abad 21 membuat proses pembelajaran pun harus berubah melalui adaptasi dengan pembelajaran online. Adanya modul berbasis weblog bisa digunakan baik pada saat pembelajaran online ataupun offline karena weblog dibuka pada laman web yang dibisa dibuka kapan saja dan dimana saja. Sedangkan hubungan pembelajaran online dengan IPTEK adalah tentang waktu belajar yang secara langsung seperti daring, webinar dan lain sebagainya.

Peneliti melakukan observasi awal di SMAN 6 Kota Jambi yang sudah mulai beradaptasi dengan pembelajaran secara online mulai Maret 2020. Semenjak masa pandemi covid-19 pembelajaran yang dilakukan mulai pertengahan semester genap tahun ajaran 2019/2020 hingga semester ganjil 2020/2021 dialihkan ke Whatsapp Group (WAG) dengan cara mengirim sumber

Jurnal Sikola: Jurnal Kajian Pendidikan dan Pembelajaran Vol. 2, No. 4, Th. 2021 
belajar peserta didik ke grup mata pelajaran di setiap kelasnya dan untuk bahan ajar yang dikirimkan ke Whatsapp Group (WAG) diambil dari internet berupa PDF. Selanjutnya pada semester ganjil tahun ajaran 2020/2021 pembelajaran dialihkan dari Whatsapp Group (WAG) ke e-learning sekolah ataupun google classroom yang dibuat oleh guru. Perubahan yang terjadi ada pada aplikasi perangkat lunak untuk kegiatan dalam jaringan, program pembelajaran elektronik atau Learning Management System (LMS). Awal semester tepatnya dua bulan pembelajaran di semester genap pada tahun 2020/2021 sistem pembelajaran masih full daring, pada tanggal 17 Februari 2021 pembelajaran mulai diuji coba tatap muka dengan sistem shift A dan shift B sesuai dengan peraturan yang ada di buku panduan penyelenggaraan pembelajaran dengan program kesetaraan menjaga jarak dan maksimal 18 orang peserta didik per kelas. Minggu pertama shift A belajar tatap muka dan shift B sistem online dengan menggunakan e-learning sekolah dan WhatsApp Group (WAG) dan begitu juga sebaliknya jika minggu depan shift B pembelajaran melalui tatap muka maka shifA pembelajaran dengan sistem online. Pembelajaran tatap muka pun dibatasi yang normalnya 45 menit per jam pembelajaran sekarang hanya diberi waktu 20 menit per jam pembelajaran. Singkatnya waktu pembelajaran membuat interaksi antara peserta didik dan guru tidak maksimal sehingga hanya memberikan poin penting pada materi dan ketika jam habis guru memberi peserta didik tugas, untuk kembali memperbanyak membaca buku paket dan bahan ajar yang diberikan.

Permasalahan yang didapatkan setelah observasi adalah pada saat pembelajaran dilakukan melalui e-learning dengan alamat sebagai berikut https://learn.sman6jambi.sch.id/ materi ajar guru dan sumber belajar banyak diambil dari internet, tidak membuat materi ajar sendiri sesuai dengan karakteristik fenomena yang tepat pada materi tersebut. Banyak bahan ajar yang hanya memfokuskan pada konsep, sehingga tidak integral dengan rancangan pembelajaran yang dibuat dan belum tentu sepenuhnya sesuai dengan indikator yang dikembangkan untuk materi tersebut. Selain bahan ajar dari portal e-learning, sumber belajar peserta didik di SMAN 6 Kota Jambi hanya berbentuk buku cetak yang diberikan oleh pihak sekolah. Apabila peserta didik belum paham tentang materi pada buku paket yang diberikan oleh sekolah, maka peserta didik berusaha mencari tambahan referensi dari internet.

Dapat dikatakan Learning Management System (LMS) yang dirancang belum berfungsi untuk mendorong proses pembelajaran supaya berjalan sesuai dengan harapan. Artinya apa yang dirancang guru dalam RPP belum terintegrasi ke dalam proses pembelajaran. Peserta didik lebih banyak mengerjakan tugas mencatat apa yang ada dalam sumber belajar yaitu buku cetak dan bahan ajar kemudian menguploadnya. Sementara pembelajaran sosiologi sangat erat dengan fenomena sosial yang ada di lingkungan sekitar peserta didik, tetapi bahan ajar yang diberikan seolah-olah terpisah dari esensi materi sosiologi yang seharusnya dipahami oleh peserta didik. Pembelajaran sosiologi juga tidak bisa hanya berupa konsep harus dihubungkan dengan dunia nyata atau pada kehidupan sehari hari. Modul yang dapat dijadikan jembatan penghubung antara materi pembelajaran dengan kehidupan sehari hari peserta didik sangat jarang dikembangkan oleh guru. Bahan ajar berbentuk cetak masih banyak yang kurang mengedepankan nilai dari unsur lingkungan dan budaya lokal masyarakat setempat (Laksana, Kurniawan, \& Niftalia, 2016).

Kelemahan lain dari materi ajar yang diperoleh peserta didik dari link internet yang disematkan guru dalam e-learning ini antara lain; terbatasnya kapasitas penyimpanan pada $e$ learning bahwa setiap dokumen tidak dapat tersimpan secara permanen, tidak sinkron dengan rancangan pembelajaran, kebutuhan pembelajaran tidak bisa diketahui dan tidak konsisten. Pada hal semestinya pembelajaran konsisten antara apa yang direncanakan, implementasi dan evaluasi. Dengan membuat rancangan pembelajaran yang konsisten dan sesuai dengan karakteristik materi serta peserta didiknya hingga tercapai tujuan dari pendidikan. Pada intinya sejauh ini belum terlihat guru merancang sebuah bahan ajar sendiri, apalagi sampai membuat bentuk bahan ajar dengan semenarik mungkin. Sehingga hasil yang diperoleh peserta didik juga belum memuaskan. Hal ini dapat dilihat dari data hasil ulangan harian peserta didik masih dibawah rata-rata

Jurnal Sikola: Jurnal Kajian Pendidikan dan Pembelajaran Vol. 2, No. 4, Th. 2021 

dikarenakan pembelajaran yang kurang efektif. Pada tabel 1 terdapat data skor ujian harian pada materi kelompok sosial di kelas XI IPS 3.

Tabel 1. Skor UH Materi Kelompok Sosial di Kelas XI IPS 3

\begin{tabular}{ccc}
\hline \multirow{2}{*}{ No } & \multicolumn{3}{c}{ Kelas XI IPS 3 } \\
\cline { 2 - 3 } & Nilai UH & Jumlah \\
\hline 1 & 80 & 1 \\
\hline 2 & 70 & 3 \\
\hline 3 & 60 & 9 \\
\hline 4 & 50 & 10 \\
\hline 5 & 40 & 1 \\
\hline 6 & 30 & 4 \\
\hline 7 & 20 & 2 \\
\hline 8 & 10 & - \\
\hline 9 & 0 & 2 \\
\hline 10 & Tidak hadir &
\end{tabular}

Sumber: Buku Nilai Peserta Didik Kelas XI IPS 3 Tahun Ajaran 2020/2021

Data di atas memperlihatkan bahwa peserta didik memiliki tingkat pemahaman yang rendah terhadap materi yang mereka pelajari. Faktor yang mendorong hal ini terjadi diantaranya bahan ajar yang diperoleh oleh peserta didik dari e-learning belum menggambarkan implementasi konsep yang dipelajari secara kontekstual. Sanjaya (dalam Karim, 2017) Ia mengemukakan bahwa metode pembelajaran kontekstual merupakan metode pembelajaran yang menekankan sepenuhnya keikutsertaan peserta didik dalam memahami materi pembelajaran dan menghubungkannya dengan kehidupan nyata, sehingga mendorong peserta didik untuk mengaplikasikannya dalam kehidupannya. Peserta didik berpartisipasi aktif dalam metode pembelajaran kontekstual menafsirkan, pembelajaran yang telah diberikan dan mengaplikasikan dalam kehidupan sehari-hari.

Dapat dijelaskan untuk mengatasi permasalahan yang ada di Learning Management System (LMS) karena bahan ajar tidak terintegrasi yang membuat peserta didik harus membuka satu persatu, maka peneliti mengintegrasikan bahan ajar, media dan sebagainya dalam sebuah modul berbasis weblog. Tingginya minat menggunakan blog di Indonesia menjadi inspirasi baru tentunya bagi para pendidik. Banyak guru telah menggunakan media ini sebagai alat komunikasi dan pusat pembelajaran di sekolah. Hal ini sangat efektif karena banyaknya pengguna Internet di Indonesia yang sebagian besar sudah menggunakannya. Tentu saja, Jika teknologi dapat beradaptasi dengan kebutuhan media dan sumber pengajaran, maka dapat membantu guru dan peserta didik dalam mengajar serta belajar di sekolah (Sartono, 2016). Menurut Nasution (2015) pembelajaran berbasis web berarti memanfaatkan teknologi informasi berupa internet dan komputer dapat digunakan untuk menyediakan materi pembelajaran melalui website, email, milis, newsgroup, dan lain-lain.

Weblog merupakan sebuah inovasi yang sangat membantu untuk mengubah proses pembelajaran. Pada saat proses pembelajaran tidak lagi sekedar mendengarkan penjelasan materi oleh guru, tetapi memungkinkan peserta didik untuk terlibat dalam kegiatan lain, seperti membaca, mengamati dan menjawab pertanyaan, mengumpulkan data, menghubungi dan berkomunikasi. Materi pembelajaran dapat ditampilkan dalam berbagai format, dan juga dapat ditampilkan dengan cara yang lebih dinamis dan interaktif untuk mendorong peserta didik berpartisipasi lebih aktif dalam proses pembelajaran. (Putri \& Hernawan, 2015, pp. 35-36). Blog sebagai salah satu layanan aplikasi dari internet, sesungguhnya adalah sebuah website. Perbedaan antara website dengan blog adalah blog tidak membutuhkan peralatan dan software khusus karena blog sudah tersedia oleh penyedia blog seperti blogger.com, wordpress.com, multiplay.com, blogdrive.com, blogsome.com, livejournal.com (Sari, Saputro, \& Saputro, 2014). Kristiyanti (2011) menyatakan bahwa guru dapat menggunakan blog dalam pembelajaran dengan mudah, tidak berbayar, dan 
cepat tanpa melakukan koding HTML secara manual untuk meletakkan, mengisi, dan menampilkan artikel secara otomatis ditampilkan di halaman blog.

Di lingkungan Sekolah Menengah Atas (SMA), manfaat dari proses pembelajaran yang dilakukan dengan bantuan modul berbasis weblog adalah dapat mengatasi berbagai kendala dalam pembelajaran konvensional terutama keterbatasan materi ajar dan sumber belajar. Sumber belajar peserta didik yang awalnya berupa buku paket dari sekolah dan bahan ajar yang diunggah guru ke e-learning berupa bahan ajar yang diambil dari internet berupa PDF sekarang menjadi bahan ajar yang berupa modul berbasis weblog yang diolah oleh guru mata pelajaran tersebut. Guru dapat mengunggah peta kompetensi, peta konsep, ulasan materi yang disertai dengan contoh baik berupa gambar atau video yang dikaitkan dengan kehidupan sehari-hari peserta didik dan beberapa pertanyaan apersepsi yang sangat mudah diakses. Pada saat guru ingin mempemperbarui materi maka guru dapat dengan cepat mengupgrade pembaruan modul.

Berdasarkan uraian permasalahan diatas, melalui modul pada pembelajaran sosiologi berbasis weblog ini, peserta didik dapat mengakses materi kapan saja dan dimana saja pada saat dibutuhkan agar bisa mengulang materi yang belum dipahami (Putri \& Hernawan, 2015). Selain itu, dalam pembelajaran menggunakan modul berbasis weblog, guru dapat mensinkronkan antara pendekatan yang digunakan, bahan ajar, LKPD, media pembelajaran dan evaluasi terhadap pemahaman peserta didik dalam satu rangkaian, tidak terpisah-pisah seperti pada aplikasi $e$ learning. Peserta didikpun mampu mengaplikasikan perangkat modul tersebut untuk membantu mereka memahami materi berdasarkan masalah yang dijumpai dalam kehidupan sehari-hari.

\section{Metode Penelitian}

Metode penelitian menggunakan pendekatan kuantitatif tipe penelitian metode eksperimen dengan rancangan penelitian one group pretest-posttest design. Desain ini ingin mengetahui peningkatan keterampilan proses sains dan hasil belajar peserta didik sesudah diterapkan perlakuan (Kurniawan, 2018). Pengumpulan data berupa instrumen yang berbentuk soal tes yang terdiri dari pretest dan posttest. Nilai yang diambil di sini adalah nilai kognitif dan psikomotorik. Sumber data pada penelitian ini bersumber dari data primer yang diperoleh langsung dari peserta didik kelas XI di SMAN 6 Kota Jambi. Subjek penelitiannya adalah peserta didik di kelas XI IPS 3 yang berjumlah 35 orang. Analisis data tentang efektivitas modul pada pembelajaran sosiologi berbasis weblog dilakukan dengan uji-t, sehingga perlu untuk melakukan tes normalitas dan homogenitas terlebih dahulu.

\section{Hasil dan Pembahasan}

Penelitian ini telah menguji coba produk berupa sebuah modul pada pembelajaran sosiologi berbasis weblog pada peserta didik di kelas XI IPS SMAN 6 Kota Jambi yang dikembangkan menggunakan software WordPress. Pada pembelajaran sosiologi materi kekerasan yang terdapat pada Kompetensi Dasar (KD) 3.4 dan 4.4 kelas XI. Secara teknis, pembuatan blog tidaklah rumit karena tidak memerlukan keahlian pemrograman dan langkah-langkah yang rumit (Wahyudi, 2014). Weblog merupakan salah satu media belajar berbasis multimedia yang ditunjang oleh beberapa fitur dan beberapa program didalamnya. Sehingga dengan memanfaatkan blog sebagai media pembelajarannya guru sudah memberikan suasana belajar yang berbeda bagi peserta didiknya. Kehadiran sarana multimedia blog cukup memberi warna pada proses pendidikan di kelas (Sulasmianti, 2019). Dibawah ini adalah gambar halaman utama desain modul berbasis weblog yang dikembangkan. 
Yumna Aulia Putri, Ike Sylvia Efektivitas Modul Dalam Pembelajaran Sosiologi Berbasis Weblog di SMAN 6 Kota Jambi

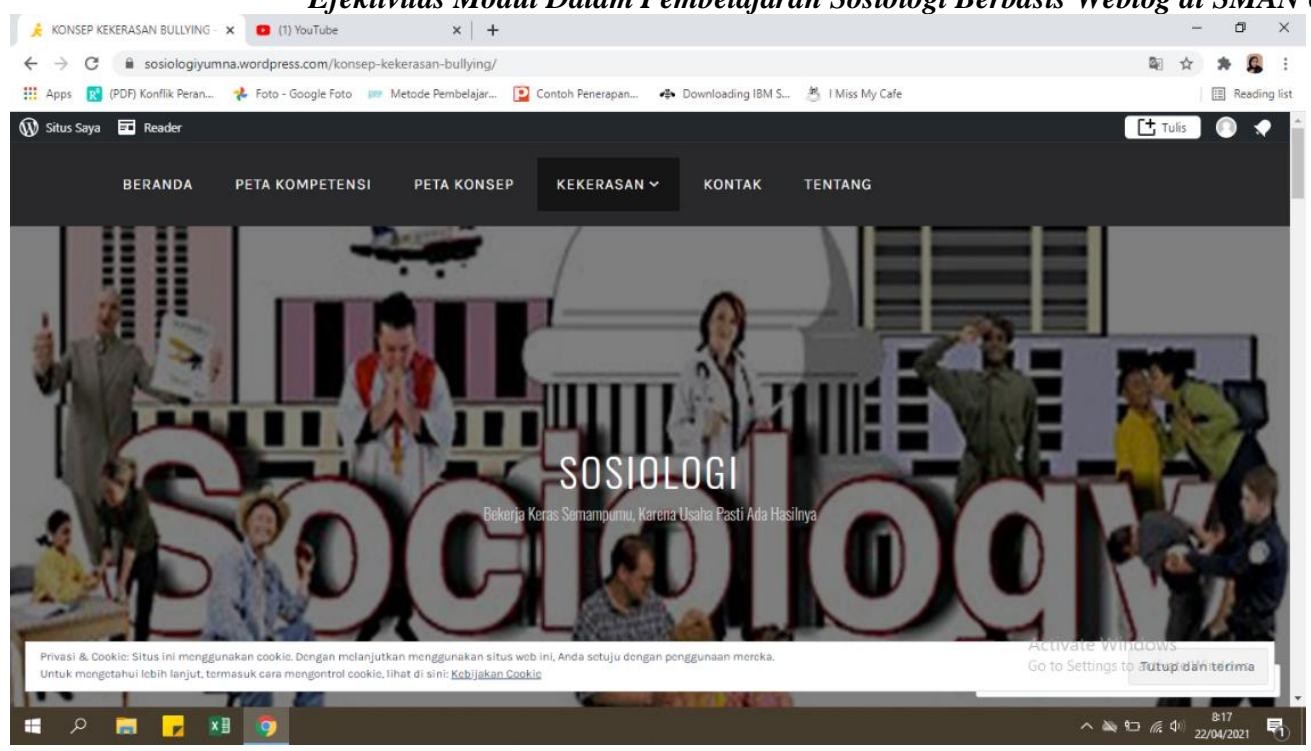

Gambar 1. Halaman Utama Modul Sosiologi Berbasis Weblog Sumber: https://sosiologiyumna.wordpress.com/

Sistem WordPress memiliki banyak bentuk, diantaranya berbasis web, desktop, dan seluler begitupula dengan tampilan blog memiliki berbagai macam bentuk, ini dapat disesuaikan dengan keinginan dari pemilik blog (Pratiwi, Santoso, Mardianto, Sediyono, \& Jurusan, 2020). Pemilihan tata letak dan desain blog menjadi penentu atau ciri khas dari suatu blog. Modul pada pembelajaran sosiologi berbasis weblog ini harus diuji efektivitasnya sebelum disebarluaskan. Menurut Siagian (dalam Islami \& Armiati, 2020, p. 501) efektivitas pada dasarnya menunjukan tingkat ketercapaiannya hasil sedangkan jika dilihat dari arti efisiensi lebih kepada bagaimana cara mencapai hasil dengan maksimal tetapi dengan sumber daya yang minimal dengan membandingkan antara output dan inputnya. Efektivitas ini menunjukan ketercapaian dari berbagai segi dan tercapainya atau sasaran yang telah dirancang tersebut. Jika hasil tersebut mendekati sasaran atau tujuan maka semakin tinggi pula efektivitasnya. Keefektifan modul pada pembelajaran sosiologi berbasis weblog yang dikembangkan ditinjau dari hasil belajar pada peserta didik baik sebelum dan sesudah perlakuan diberikan yaitu berupa modul pada pembelajaran sosiologi berbasis weblog. Soal pretest dan posttest diberikan kepada peserta didik di kelas XI IPS 3 SMAN 6 Kota Jambi terdiri dari 15 soal pilihan ganda dengan peserta didik yang berjumlah sebanyak 35 orang. Pada tabel 2 dijelaskan kisi-kisi soal yang akan di tes kepada peserta didik.

Tabel 2. Kisi-Kisi Soal Pretest dan Posttest

\begin{tabular}{|c|c|c|c|c|c|c|c|}
\hline No & $\begin{array}{l}\text { Kompetensi } \\
\text { Dasar }\end{array}$ & Materi & $\begin{array}{l}\text { Kelas/ } \\
\text { Semester }\end{array}$ & Indikator Soal & $\begin{array}{l}\text { Level } \\
\text { Kog- } \\
\text { nitif }\end{array}$ & $\begin{array}{c}\text { Bentuk } \\
\text { Soal }\end{array}$ & $\begin{array}{l}\text { No. } \\
\text { Soal }\end{array}$ \\
\hline 1 & $\begin{array}{l}\text { 3.4 Menganalisis } \\
\text { konflik sosial dan } \\
\text { cara memberikan } \\
\text { respons untuk }\end{array}$ & Kekerasan & $\begin{array}{l}\text { XI/ } \\
\text { Genap }\end{array}$ & $\begin{array}{l}3.4 .8 \\
\text { Menganalisis } \\
\text { pengertian } \\
\text { kekerasan }\end{array}$ & $\mathrm{C} 4$ & $\begin{array}{l}\text { Pilihan } \\
\text { ganda }\end{array}$ & $\begin{array}{l}1,3,4, \\
10,11 \\
, 12\end{array}$ \\
\hline 2 & $\begin{array}{l}\text { melakukan } \\
\text { resolusi konflik } \\
\text { demi terciptanya } \\
\text { kehidupan yang }\end{array}$ & & $\begin{array}{l}\text { XI/ } \\
\text { Genap }\end{array}$ & $\begin{array}{l}3.4 .9 \\
\text { Menjelaskan } \\
\text { keterkaitan } \\
\text { kekerasan dan } \\
\text { teori }\end{array}$ & $\mathrm{C} 2$ & $\begin{array}{l}\text { Pilihan } \\
\text { ganda }\end{array}$ & $\begin{array}{l}2,6,8, \\
13, \\
15\end{array}$ \\
\hline
\end{tabular}

Jurnal Sikola: Jurnal Kajian Pendidikan dan Pembelajaran Vol. 2, No. 4, Th. 2021 
Yumna Aulia Putri, Ike Sylvia Efektivitas Modul Dalam Pembelajaran Sosiologi Berbasis Weblog di SMAN 6 Kota Jambi

\begin{tabular}{|c|c|c|c|c|c|c|}
\hline 3 & $\begin{array}{l}\text { damai di } \\
\text { masyarakat. } \\
\text { 4.4Memetakan } \\
\text { konflik untuk } \\
\text { dapat melakukan } \\
\text { resolusi konflik }\end{array}$ & $\begin{array}{l}\text { XI/ } \\
\text { Genap }\end{array}$ & $\begin{array}{l}3.4 .10 \\
\text { Menganalisis } \\
\text { KDRT sebagai } \\
\text { sebuah } \\
\text { tindakan } \\
\text { kekerasan. }\end{array}$ & C4 & $\begin{array}{l}\text { Pilihan } \\
\text { ganda }\end{array}$ & $5,7,8$ \\
\hline 4 & $\begin{array}{l}\text { dan } \\
\text { menumbuhkemb } \\
\text { angkan } \\
\text { perdamaian di } \\
\text { masyarakat. }\end{array}$ & $\begin{array}{l}\text { XI/ } \\
\text { Genap }\end{array}$ & $\begin{array}{l}3.4 .11 \\
\text { Menganalisis } \\
\text { bullying sebagai } \\
\text { sebuah } \\
\text { tindakan } \\
\text { kekerasan. }\end{array}$ & C4 & $\begin{array}{l}\text { Pilihan } \\
\text { ganda }\end{array}$ & $\begin{array}{l}9.10, \\
14\end{array}$ \\
\hline
\end{tabular}

Sumber: Data Primer 2021

Soal di susun berdasarkan kisi-kisi yang telah dibuat. Skor pretest akan dibandingkan dengan hasil posttest sehingga dapat diketahui apakah kegiatan belajar mengajar berhasil baik atau tidak dan diharapkan pemahaman peserta didik lebih baik terhadap materi yang diberikan dan memotivasi peserta didik untuk sungguh-sungguh dalam memperhatikan pelajaran sehingga dapat meningkatkan hasil belajar peserta didik (Effendy, 2016). Setelah melakukan penelitian dan memberikan soal pretest dan posttest maka didapatkan hasil rekapitulasi nilai data pretest dan posttest peserta didik kelas XI IPS 3 SMAN 6 Kota Jambi yang terdapat pada tabel 2 di bawah ini.

Tabel 2. Disajikan Rekapitulasi Hasil Data Pretest Dan Posttest Peserta Didik Kelas XI IPS 3 SMAN 6 Kota Jambi

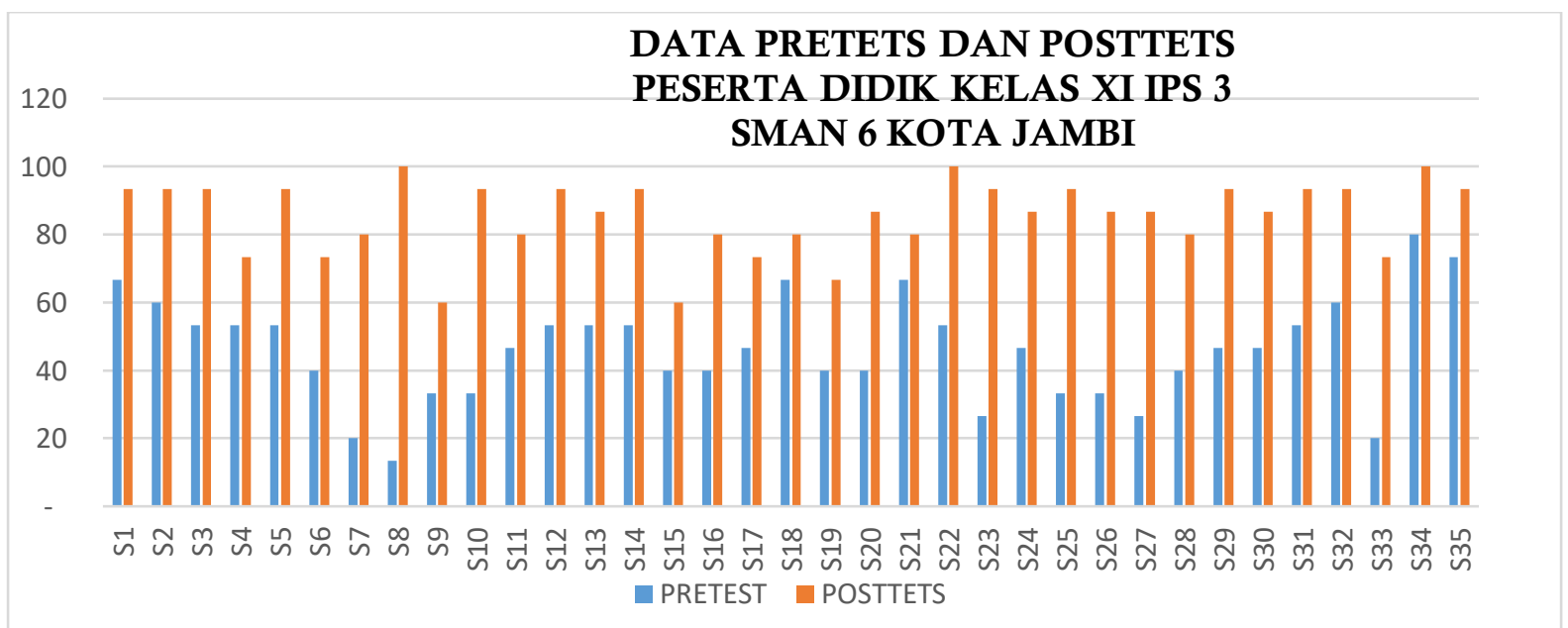

Sumber: Data Primer 2021

Data rekapitulasi hasil pretest dan posttest ditampilakan pada tabel 1 diatas, dari jumlah 35 peserta didik yang di uji terdapat peningkatan hasil materi yang diberikan dari pretest dan posttest. Sedangkan data hasil belajar kognitif dengan perolehan nilai melalui nilai pretest dan posttest, dapat dilihat pada Tabel 3 dibawah ini. 
Table 3. Hasil Belajar Kognitif IPS 3

\begin{tabular}{lrrrrr}
\hline \multicolumn{7}{c}{ Descriptive Statistics } \\
\hline & N & \multicolumn{1}{c}{ Minimum } & Maximum & Mean & \multicolumn{1}{c}{ Std. Deviation } \\
\hline Pretest & 35 & 13.00 & 80.00 & 46.0000 & 16.03122 \\
\hline Posttest & 35 & 60.00 & 100.00 & 86.0571 & 10.47670 \\
\hline Valid N (listwise) & 35 & & & & \\
\hline
\end{tabular}

Sumber: Data Primer 2021

Berdasarkan data hasil belajar kognitif, diketahui rata-rata hasil belajar kognitif sebelum peserta didik diberi perlakuan berupa penerapan modul pada pembelajaran sosiologi berbasis weblog sebesar 46,00 dengan std. deviation 16,031 dan nilai minimum yang didapatkan 13 serta nilai maksimum 80 . Rata-rata hasil belajar kognitif setelah diberi perlakuan berupa penerapan modul pada pembelajaran sosiologi berbasis weblog sebesar 86,06 dengan std. deviation 10,477 dan nilai minimum yang didapatkan 60 serta nilai maksimum 100 .

Ditinjau dari uji-t sebelum dilaksanakan pengujian hipotesis, perlu adanya uji prasyarat analisis terlebih dahulu. Uji persyaratan analisis yaitu sebuah analisis normalitas yang bertujuan melihat normal ataupun tidaknya data dan analisis homogenitas bertujuan untuk melihat varian data sama atau tidak. Uji normalitas dan uji homogenitas dilaksanakan dengan menggunakan aplikasi IBM SPSS 25. Uji normalitas adalah suatu prosedur yang digunakan untuk mengetahui apakah data berasal dari populasi yang berdistribusi normal atau berada dalam sebaran normal (Nuryadi, Astuti, Utami, \& Budiantara, 2017). Uji normalitas memiliki tujuan mengetahui apakah ada nilai residual yang berdistribusi normal atau tidak. Uji kolmogorov smirnov termasuk bagian dari uji asumsi klasik. Hasil analisis uji normalitas menggunakan uji kolmogororov-smirnov dengan data kelas XI IPS 3 disajikan pada tabel 4 berikut ini:

Tabel 4. Hasil Analisis Uji Normalitas One-Sample Kolmogorov-Smirnov Test

\begin{tabular}{llr}
\hline & & \multicolumn{2}{c}{$\begin{array}{c}\text { Unstandardized } \\
\text { Residual }\end{array}$} \\
\hline $\mathrm{N}$ & & 35 \\
\hline Normal Parameters ${ }^{\mathrm{a}, \mathrm{b}}$ & Mean & .0000000 \\
\cline { 2 - 3 } & Std. Deviation & 10.24108842 \\
\hline Most Extreme Differences & Absolute & .154 \\
\cline { 2 - 3 } & Positive & .085 \\
\cline { 2 - 3 } & Negative & -.154 \\
\hline Test Statistic & & .154 \\
\hline Asymp. Sig. (2-tailed) & & $.034^{\mathrm{c}}$ \\
\hline Sumber: Data Primer & &
\end{tabular}

Sumber: Data Primer 2021

Berdasarkan tabel 4 One Sample Kolmogorov-Smirnov Test digunakan untuk uji normalitas pada data yang menggunakan satu sampel (Herawati, 2016). Jika nilai Signifikansi $>0,05$, dapat dikatakan nilai residual berdistribusi normal dan jika nilai Signifikansi $<0,05$, dapat dikatakan nilai residual tidak berdistribusi normal. Berdasarkan hasil penelitian seperti tertera pada tabel 4 diatas bahwa dari perhitungan analisis uji normalitas diperoleh jumlah nilai signifikansi untuk pretest sebesar 0,034 yang berarti $>0,05$ dengan begitu dapat disimpulkan data hasil belajar peserta didik berdistribusi normal dan dapat dilanjutkan dengan uji homogenitas. Uji homogenitas adalah suatu prosedur uji statistik yang dimaksudkan untuk memperlihatkan bahwa dua atau lebih 
kelompok data sampel berasal dari populasi yang memiliki variansi yang sama (Nuryadi et al., 2017). Pengujian dengan uji homogenitas merupakan sebuah persyaratan sebelum melakukan pengujian lain, misalnya $\mathrm{T}$ Test. Pengujian ini dapat digunakan untuk meyakinkan bahwa kelompok data memang berasal dari populasi yang memiliki varians yang sama (homogen). Hasil analisis uji homogenitas data kelas XI IPS 3 disajikan pada tabel 5 berikut ini:

Tabel 5. Hasil Analisis Uji Homogenitas Test of Homogeneity of Variances

\begin{tabular}{llrrrrr}
\hline & \multicolumn{2}{c}{$\begin{array}{c}\text { Levene } \\
\text { Statistic }\end{array}$} & df1 & df2 & \multicolumn{1}{c}{ Sig. } \\
\hline $\begin{array}{l}\text { Hasil Belajar } \\
\text { Sosiologi }\end{array}$ & Based on Mean & 3.427 & 1 & 68 & .068 \\
\cline { 2 - 7 } & Based on Median & 3.575 & 1 & 68 & .063 \\
\cline { 2 - 7 } & $\begin{array}{l}\text { Based on Median and } \\
\text { with adjusted df }\end{array}$ & 3.575 & 1 & 61.106 & .063 \\
\cline { 2 - 7 } & Based on trimmed mean & 3.668 & 1 & 68 & .060 \\
\hline
\end{tabular}

Sumber: Data Primer 2021

Jika nilai Signifikansi $>0,05$, dapat dikatakan distribusi data homogen dan jika nilai Signifikansi <0,05, dapat dikatakan distribusi data tidak homogen. Berdasarkan hasil dari perhitungan analisis uji homogenitas diperoleh nilai signifikansi untuk sebesar 0,068 yang berarti lebih besar dari 0,05 maka dapat disimpulkan bahwa data hasil belajar peserta didik berdistribusi normal $0,068>0,05$, artinya data soal pretest dan posttest memiliki varians yang sama atau homogen dan dapat dilanjutkan dengan pengujian hipotesis. Hasil analisis uji hipotesis data kelas XI IPS 3 disajikan pada tabel 6 berikut ini:

Tabel 6. Hasil Analisis Uji Hipotesis Paired Samples Test

\begin{tabular}{|c|c|c|c|c|c|c|c|c|c|}
\hline & \multicolumn{5}{|c|}{ Paired Differences } & \multirow[b]{3}{*}{$\mathrm{t}$} & \multirow[b]{3}{*}{$\mathrm{df}$} & \multirow{3}{*}{$\begin{array}{l}\text { Sig. (2- } \\
\text { tailed) }\end{array}$} \\
\hline & & \multirow[b]{2}{*}{ Mean } & \multirow{2}{*}{$\begin{array}{l}\text { Std. } \\
\text { Deviati } \\
\text { on }\end{array}$} & \multirow{2}{*}{$\begin{array}{l}\text { Std. } \\
\text { Error } \\
\text { Mean }\end{array}$} & \multicolumn{2}{|c|}{$\begin{array}{l}95 \% \text { Confidence } \\
\text { Interval of the } \\
\text { Difference }\end{array}$} & & & \\
\hline & & & & & Lower & Upper & & & \\
\hline Pair & Pretest - & - & 19.1663 & 3.23971 & - & - & - & 34 & .000 \\
\hline 1 & Posttest & $\begin{array}{r}40.05 \\
714\end{array}$ & 7 & & $\begin{array}{r}46.6410 \\
2\end{array}$ & $\begin{array}{r}33.4732 \\
7\end{array}$ & $\begin{array}{r}12.3 \\
64\end{array}$ & & \\
\hline
\end{tabular}

Sumber: Data Primer 2021

Analisis uji t berpasangan (paired sample test) digunakan sebagai alat pengujian hipotesis. Uji $\mathrm{T}$ Dua Sampel yang berpasangan diartikan sebagai sebuah sampel dengan subyek yang sama namun mengalami dua perlakuan atau pengukuran yang berbeda (Singgih Santoso 2012). Nilai signifikansi yang terdapat di table 6 sebesar $0,000(0,000<0,05)$ yang dapat disimpulkan bahwa terdapat perbedaan yang signifikan hasil belajar peserta didik kelas XI IPS 3 SMAN 6 Kota Jambi sebelum dan sesudah diberikan perlakuan yaitu modul pada pembelajaran sosiologi berbasis weblog.

Dengan menggunakan teori konstruktivistik yang dikemukakan oleh Piaget dapat dipahami bahwa hasil penelitian ini menekankan bahwa pengetahuan adalah konstruksi (bentukan) sendiri dan serta perkembangan kognitif adalah suatu proses dimana peserta didik secara aktif membentuk sistem arti dan pemahaman terhadap realita melalui pengalaman dan hubungan mereka (Cristiyanda \& Sylvia, 2021). Istilah proses pembelajaran tidak lagi berpusat dalam guru, guru

Jurnal Sikola: Jurnal Kajian Pendidikan dan Pembelajaran Vol. 2, No. 4, Th. 2021 
Yumna Aulia Putri, Ike Sylvia

Efektivitas Modul Dalam Pembelajaran Sosiologi Berbasis Weblog di SMAN 6 Kota Jambi sebagai fasilitator wajib bisa menerapkan suasana belajar yang melibatkan peserta didik secara aktif pada proses pembelajaran. Peserta didik akan aktif berada pada pembelajaran yang sanggup menciptakan mereka untuk melakukan kegiatan seperti berbicara, menyampaikan pendapat, membaca, menulis dan interaksi antar teman sekolah dan juga guru.

Berdasarkan literature review dihasilkan bahwa penggunaan modul berbasis weblog sangat efektif diterapkan dalam aktivitas belajar. Didukung pula oleh pendapat yang menyatakan mengenai indikator sesuatu mampu dikatakan efektif menurut Sinambela (2019), pembelajaran dikatakan efektif jika mencapai target yang diinginkan, baik berdasarkan segi tujuan pembelajaran juga prestasi peserta didik yang maksimal. Beberapa indikator keefektifan pembelajaran: (a) Ketercapaian ketuntasan belajar, (b) Ketercapaian keefektifan aktivitas peserta didik dan, (c) Ketercapaian efektivitas kemmapuan guru mengelola pembelajaran, dan respon peserta didik terhadap pembelajaran yang positif. Berdasarkan indikator menurut Sinambela di atas, dapat disimpulkan bahwa efektivitas pembelajaran merupakan tingkat keberhasilan yang bisa dicapai berdasarkan suatu metode pembelajaran tertentu sinkron dengan tujuan pembelajaran yang sudah direncanakan.

\section{Kesimpulan}

Penelitian ini telah menghasilkan sebuah produk yaitu modul pada pembelajaran sosiologi berbasis weblog yang dapat membantu peserta didik dalam proses pembelajaran. Modul berbasis weblog tersebut sudah teruji efektif digunakan untuk peserta didik karena sudah sesuai dengan hasil pengujian empiris. Kajian empiris telah dilakukan melalui pemberian pada kelas XI IPS 3 telah terbukti dengan rerata nilai akhir sebelum diberi perlakuan dan sesudah diberi perlakuan berupa modul pada pembelajaran sosiologi berbasis weblog. Dengan begitu modul pada pembelajaran sosiologi berbasis weblog yang dikembangkan dapat digunakan pada proses pembelajaran untuk meningkatkan hasil belajar peserta didik.

\section{Daftar Pustaka}

Cristiyanda, G., \& Sylvia, I. (2021). Pengaruh Penggunaan Webquiz Quizizz Terhadap Hasil Belajar Sosiologi Siswa di SMA N 16 Padang. Jurnal Sikola, 2(3), 174-183.

Depdiknas. (2008). Penulisan Modul. In Penulisan Modul. Jakarta: Depdiknas.

Dwipayana, P. A. P., Redhana, I. W., \& Juniartina, P. P. (2020). Analisis Kebutuhan Pengembangan Multimedia Interaktif Berbasis Konteks Budaya Lokal Untuk Pembelajaran IPA SMP. Jurnal Pendidikan Dan Pembelajaran Sains Indonesia, 3(1), 49-60.

Effendy, I. (2016). Pengaruh Pemberian Pre-Test dan Post-Test Terhadap Hasil Belajar Mata Diklat HDW.DEV.100.2.a pada Siswa SMK Negeri 2 Lubuk Basung. Jurnal Ilmiah Pendidikan, 1(2), 81-88.

Herawati, L. (2016). Uji Normalitas Data Kesehatan Menggunakan SPSS (A. H. Kadarusno, ed.). Yogyakarta: Poltekkes Jogja Press.

Islami, H., \& Armiati. (2020). Efektivitas Penggunaan Modul Pembelajaran Berbasis Kontekstual Pada Bidang Keahlian Bisnis Dan Manajemen Di Sekolah Menengah Kejuruan ( SMK ): Literature Review. Jurnal Ecogan, 3(4), 498-512.

Karim, A. (2017). Analisis Pendekatan Pembelajaran CTL (Contextual Teaching And Learning) di SMPN 2 Teluk Jambe Timur, Karawang. Formatif, 7(2), 144-152. https://doi.org/10.30998/formatif.v7i2.1578

Kristiyanti, M. (2011). Blog Sebagai Alternatif Media Pembelajaran. Majalah Ilmiah Infomatika, 2, 33-44.

Kurniawan, A. (2018). Metode Penelitian Pendidikan (N. Nur, ed.). Bandung: PT Remaja Rosdakarya.

Laksana, D. N. L., Kurniawan, P. A. W., \& Niftalia, I. (2016). Pengembangan Bahan Ajar Tematik SD Kelas IV Berbasis Kearifan Lokal Masyarakat Ngada. Jurnal Ilmiah Pendidikan, 3(1), 1-10.

Jurnal Sikola: Jurnal Kajian Pendidikan dan Pembelajaran Vol. 2, No. 4, Th. 2021 
Lasmiyati, \& Harta, I. (2014). Pengembangan Modul Pembelajaran untuk Meningkatkan Pemahaman Konsep dan Minat SMP. Pengembangan Modul Pembelajaran Untuk Meningkatkan Pemahaman Konsep Dan Minat SMP, 9(2), 1-14. https://doi.org/10.21831/pg.v9i2.9077

Nasution, T. (2015). Penerapan Metode Web Based Learning Sebagai Solusi Pendidikan Yang Efektif Dan Efisien. Times, 4(2), 49-52.

Nuryadi, N., Astuti, T. D., Utami, E. S., \& Budiantara, B. (2017). Dasar-Dasar Statistika Penelitian. Yogyakarta: Sibuku Media.

Pratiwi, D., Santoso, G. B., Mardianto, I., Sediyono, A., \& Jurusan, A. R. (2020). Pengelolaan Konten Web Menggunakan Wordpress , Canva dan Photoshop untuk Guru-Guru Wilayah Jakarta. Jurnal Ilmiah Pengabdian Pada Masyarakat, 2(1), 11-15.

Putri, D. I., \& Hernawan, H. (2015). Efektivitas Penggunaan Media Pembelajaran Web Centric Course Untuk Meningkatkan Pemahaman Mahasiswa Pada Mata Kuliah Embriologi di Program Studi Pendidikan Biologi STKIP Garut. STKIP Garut.

Sari, R. A., Saputro, S., \& Saputro, A. N. C. (2014). Pengembangan Modul Pembelajaran Kimia Berbasis Blog Untuk Materi Struktur Atom dan Sistem Periodik Unsur SMA Kelas XI. Jurnal Pendidikan Kimia, 3(2), 7-15.

Sartono. (2016). Pemanfaatan Blog Sebagai Media Pembelajaran Alternatif di Sekolah. Transformatika, 12(1), 120-134.

Sulasmianti, N. (2019). Pemanfaatan Blog Sebagai Media Pembelajaran. Teknodik, 22(2), 1-10. https://doi.org/10.32550/teknodik.v0i0.365

Tim Grasindo. (2017). UUD 1945 dan Amandemennya Untuk Pelajar dan Umum. Jakarta: PT. Gramedia Widiasarana Indonesia.

Wahyudi, N. (2014). Pemanfaatan Blog sebagai Media Pembelajaran Interaktif. Study Islam Panca Wahana Iahana I, (12), 84-94. https://doi.org/10.32550/teknodik.v0i0.365

Wijaya, Y. E., Sudjimat, D. A., \& Nyoto, A. (2016). Transformasi Pendidikan Abad 21 sebagai Tuntutan Pengembangan Sumber Daya Manusia Di Era Global. Prosiding Seminar Nasional Pendidikan Matematika. Universitas Kanjuruhan Malang. 